\title{
Neutral zone approach and external impression for rehabilitation of severely atrophic maxillary and mandibular ridges: a case report
}

\author{
Yujin Jo, Chang-woo Ko, Sang-Won Park, Kwi-Dug Yun, Chan Park, Hyun-Pil Lim* \\ Department of Prosthodontics, School of Dentistry, Chonnam National University, Gwangju, Republic of Korea
}

In order to produce a stable denture for severe alveolar bone loss area, it is not only important that .0a suitable occlusion is established but also to consider compatibility with the surrounding muscle to form a suitable polished surfaces. Neutral zone is defined as a potential area where the neuromuscular system of the tongue, cheeks and lips is balanced can be determined through the neutral zone impression technique. And if artificial teeth are aligned within the neutral zone and the polished surface follows the anatomical form of the dynamic muscle, higher stability and retention of the denture may be obtained through coordination with the surrounding muscle tissue. This case is being reported since the concept of the neutral zone was applied to a patient with severely atrophic residual alveolar ridge and the result was clinically satisfactory in both function and aesthetics. (J Dent Rehabil Appl Sci 2018;34(4):324-30)

Key words: complete denture; neutral zone; external impression

\begin{abstract}
서론
총의치는 말을 하거나 저작, 연하 시 구강 안팎의 혀와 입술, 볼, 구강저 등의 복잡한 요소들의 상호작용에 영 향을 받기 때문에 적절한 위치의 치아배열 및 의치의 변 연과 외형을 형성하는 것이 중요하다. 의치는 인상면, 교 합면, 연마면으로 구성되어 있으며, 치조골의 흡수가 심 한 환자의 경우 인상면보다는 연마면이 차지하는 비율이 더 높기 때문에 그 중요성이 커지게 된다. ${ }^{1}$ 연마면 형태 가 주변 근육 조직과의 조화를 잘 반영하게 된다면 근육 의 움직임 자체를 의치 안정 요소로 이용할 수 있다. 중립 대(neutral zone)는 구강 안에서 밖으로 향하는 혀의 압 력과 밖에서 안으로 향하는 볼과 입술의 압력이 평형을 이루는 잠재적인 영역으로 정의되며, 중립대 인상 기법을 이용하여 제작한 가철성 의치는 인공치아를 중립대 내에
\end{abstract}

*Correspondence to: Hyun-Pil Lim Associate Professor, Department of Prosthodontics, School of Dentistry, Chonnam National University, 33 Yongbong-ro, Buk-gu, Gwangju, 61186, Republic of Korea

Tel: +82-62-530-5638, Fax: +82-62-530-5639, E-mail: mcnihil@chonnam.ac.kr Received: August 6, 2018/Last Revision: August 30, 2018/Accepted: September 5, 2018
배열할 수 있게 하며, 연마면 형태가 동적인 근육의 해부 학적 형태를 따르도록 하여 의치의 안정과 유지 및 심미 성을 향상시킬 수 있다. ${ }^{2}$

본 증례는 협소한 상, 하악궁과 심한 하악 치조제 흡수 를 동반한 완전 무치악 환자에서 중립대 개념을 적용하 여 총의치를 제작하여 높은 안정과 유지, 만족스러운 심 미성을 얻고자 하였다.

\section{증례보고}

환자는 78세의 여성으로 오래 전에 제작한 기존의 의 치가 잘 맞지 않고 잇몸이 아프다는 주소로 내원하였다. 의과적 병력으로는 고혈압으로 약 복용 중이었으며, 약 12 년 전 대장암 수술 기왕력이 있었다. 임상검사 및 방사 선 사진을 통한 구강 내 소견으로는 심한 치조제 흡수를

Copyright@ 2018 The Korean Academy of Stomatognathic Function and Occlusion. (c) It is identical to Creative Commons Non-Commercial License. 
동반한 협소한 형태의 상,하악궁과 장기간의 무치악 상 태로 인해 발달된 혀를 볼 수 있었다(Fig. 1, 2). 안모관찰 시에는 기존 의치의 교합평면이 동공간선과 일치하지 않 아 우측경사를 보이는 비대칭이 있는 상태였다. 또한 기 존 사용 중인 의치는 전반적으로 길이가 짧고 유지력이 부족한 상태였기 때문에 새롭게 상, 하악 총의치를 제작 하기로 하였다. 특히 하악의 경우 잔존치조제가 많이 흡 수되어 근 부착이 치조정과 가까워 의치의 유지와 안정 을 얻기 어려운 상태였기 때문에 의치의 안정을 증대시키 기 위해 중립대 인상 기법을 이용하여 협, 설측 근육의 압 력이 균형이 이루는 위치에 치아를 배열하고, 근육의 움 직임을 반영하는 연마면을 형성하기로 결정하였다.

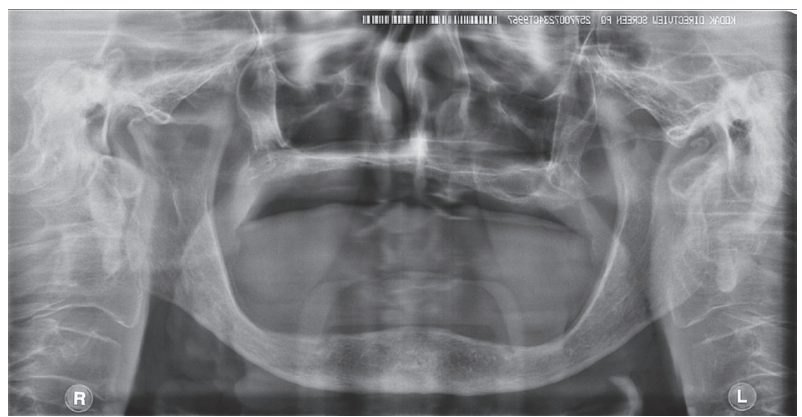

Fig. 1. Initial panoramic radiograph.
비가역성하이드로콜로이드인상재(Cavex Impressional, CAVEX, Haarlem, Netherland)로 인상 채득하 여 진단 모형 제작하였으며 진단 모형 상에서 개인 트 레이를 제작하였다. 그 후 모델링 콤파운드(Modeling Compound, Kerr Corp.)로 변연을 형성한 후 폴리설파 이드(Perlmastic, Kerr Corp., Orange, USA)를 이용하여 상, 하악의 기능 인상을 채득하고 최종 모형을 제작하였 다. 최종 모형 상에서 금속상 위에 아크릴릭 레진으로 기 록상을 제작한 후 통상적인 왁스 교합제를 이용하여 악 간 관계를 채득한 후 조금 더 재현성 있고 정확한 중심위 채득을 위해 다시 한번 더 고딕아치 묘기법을 이용한 악 간 관계를 채득을 시행하였다. 첫 번째 악간 관계 채득 시 얻어진 상,하악 교합제에 gothic arch tracer (gothic arch, Kuwoteck, Gwangju, Korea)를 설치한 후 구강 내에 장 착했다. 그리고는 손가락으로 압력을 가하여 기록상의 유지, 안정성 및 동통의 유무를 검사하고, 환자에게 좌, 우측 측방운동 및 전방운동을 시행하도록 하여 중심위 를 채득하였다(Fig. 3). 그리고 중립대를 찾기 위해 또 다 른 아크릴릭 레진 기록상을 제작하고 $1.0 \mathrm{~mm}$ wire로 콤 파운드를 유지하기 위한 골격을 형성하여 그 위에 적절 한 온도로 연화시킨 모델링 콤파운드를 소량씩 쌓아주면 서 구강 내에서 compound rim을 형성하였다(Fig. 4). 연
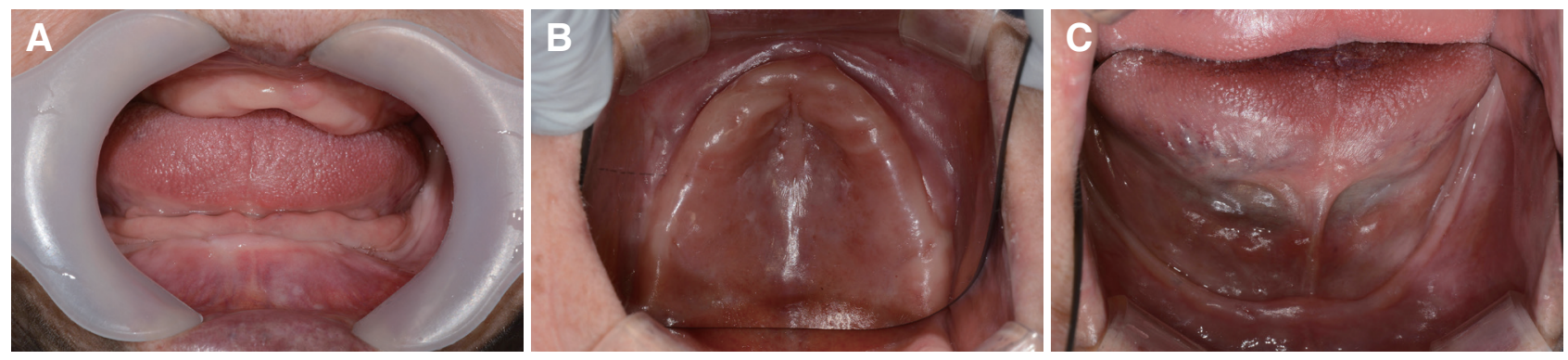

Fig. 2. Initial intraoral photographs. (A) Frontal view, (B) Occlusal view of maxilla, (C) Occlusal view of mandible.
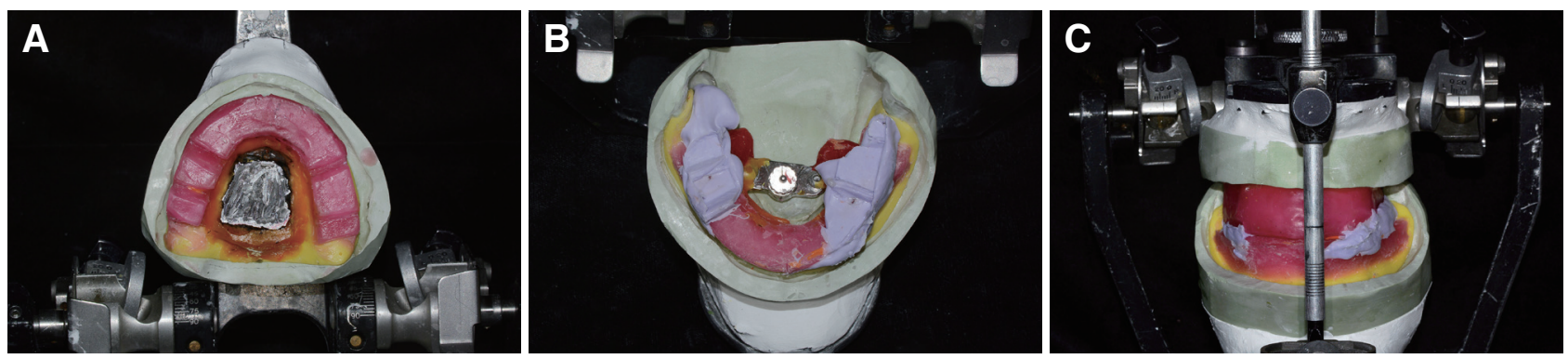

Fig. 3. Intermaxillary relation record. (A, B) Centric relation record using Gothic arch tracing, (C) Mounting of master casts. 


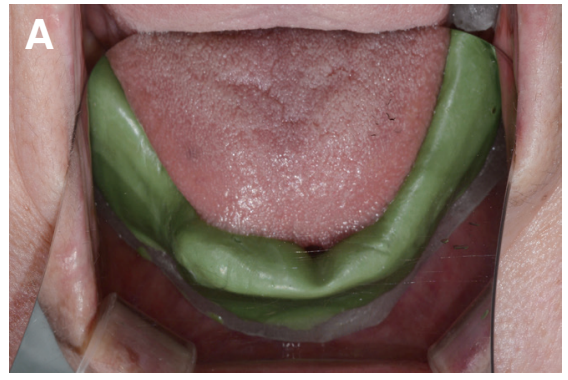

Fig. 4. Lower acrylic resin base with compound rim (A, B).

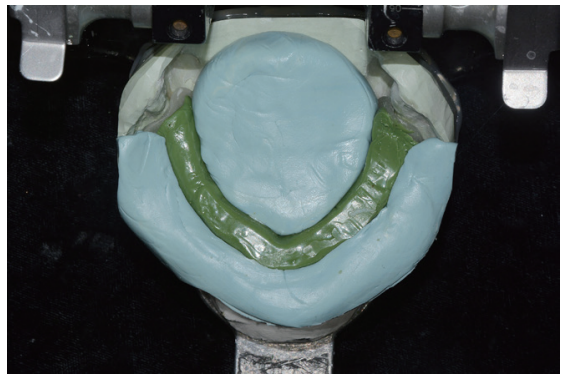

Fig. 5. Artificial tooth arrangement according to the silicone putty index.
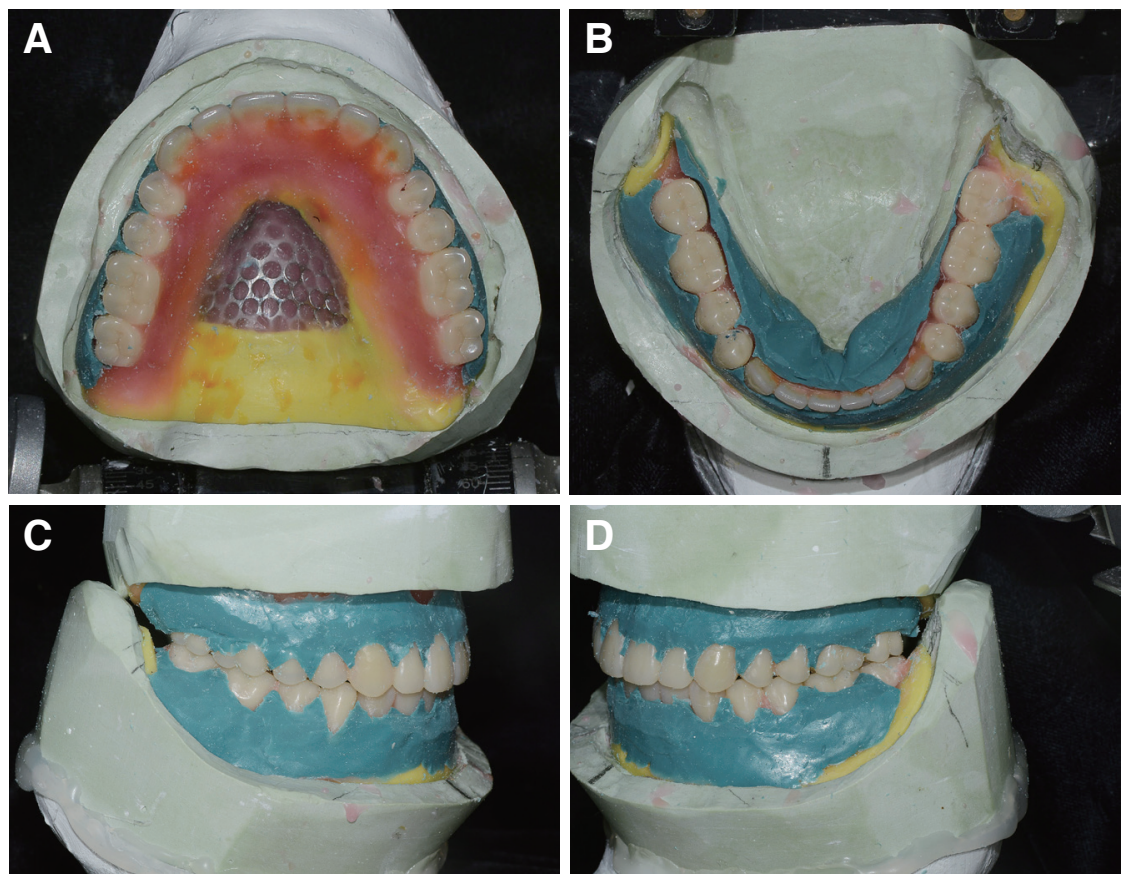

Fig. 6. External impression. (A) Maxillary occlusal view, (B) Mandibular occlusal view, (C) Right lateral view, (D) Left lateral view.

화된 compound rim을 구내에 적용 시 경화될 때까지 환 자에게 혀를 내밀거나 입술을 핝는 동작, 연하, '이(E)'와 '오 $(\mathrm{O})$ ' 발음 등의 기능 운동을 여러 차례 반복 시행하도 록 함으로써 볼과 입술, 혀의 근육 운동을 반영한 중립대 를 인기하였다.

부가중합형 실리콘 인상재(Extrude XP putty, Kerr Corp., Orange, USA)를 이용하여 중립대를 반영하는 compound rim의 형태를 복제하여 index를 제작하였 고, 이 index를 왁스 교합제에 적용하여 중립대에 치아 가 배열되도록 하였다(Fig. 5). 해부학적 치아(Endura, Shofu Inc., Kyoto, Japan)를 이용하여 양측성 균형 교합 양식으로 교합을 형성하였고, 완성된 납의치는 시적하 여 안모 및 수직고경, 교합을 평가한 후, 연마면 형성을
위해 외부인상(external impression)을 시행하였다. 상, 하악 납의치의 치은 부위 왁스를 제거 하고, 부가중합형 실리콘 인상재(Virtual Heavy Body, Ivoclar Vivadent, Liechtenstein)를 협,설 그리고 좌, 우측으로 나누어 부 분적으로 적용 후 구내 시적하여 경화 시간 동안 환자가 기능운동을 하도록 하여 각각의 연마면을 채득하였다 (Fig. 6). 의치 온성 후, 기공실 재부착 및 교합 조정 시행 하였고, 이를 연마하여 의치를 완성하였다(Fig. 7). 환자 에게 최종 의치를 시적하여 의치상의 적합과 심미성, 교 합관계를 확인하였고, 진료실 재부착 시행 후, 의치를 장 착 하였다. 최종의치 제작 후, 기존 임시 의치와 비교 하 기 위해 Geomagic ${ }^{\circledR}$ Control X' ${ }^{\mathrm{TM}}$ (Geomagic ${ }^{\circledR}$ Control $\mathrm{X}^{\mathrm{TM}}$ version 2017.0.1, Artec3D, Luxembourg) 프로그램 

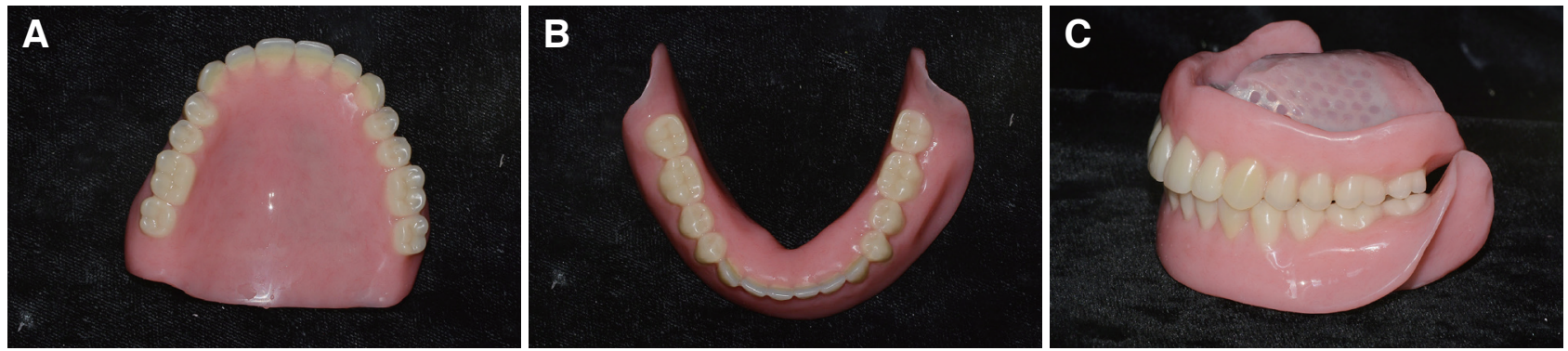

Fig. 7. Polished surface of new denture. (A) Maxillary occlusal view, (B) Mandibular occlusal view, (C) Lateral view.
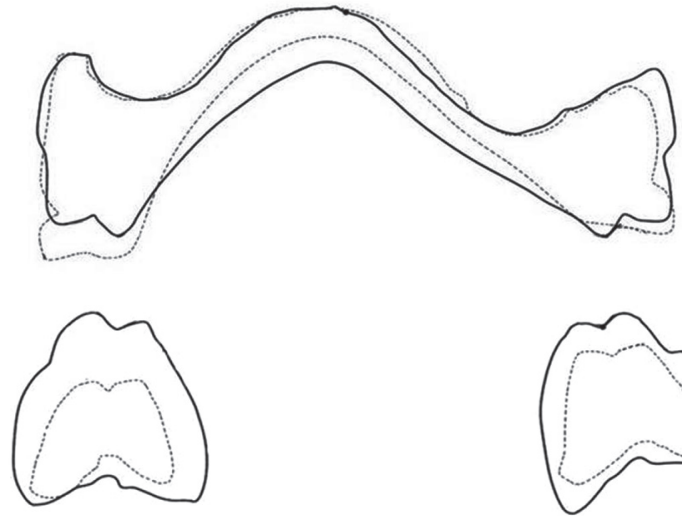

Rt. side

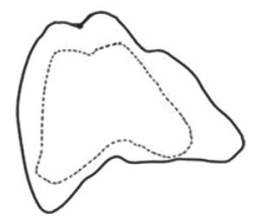

Lt. side

Fig. 8. Comparison of cross sectional view of new denture (solid line) and pre-existing denture (dotted line) at maxillary 1st molar mesioligual cusp area cross section

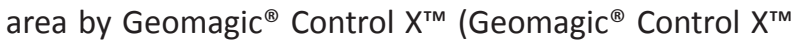
version 2017.0.1, Artec3D, Luxembourg).
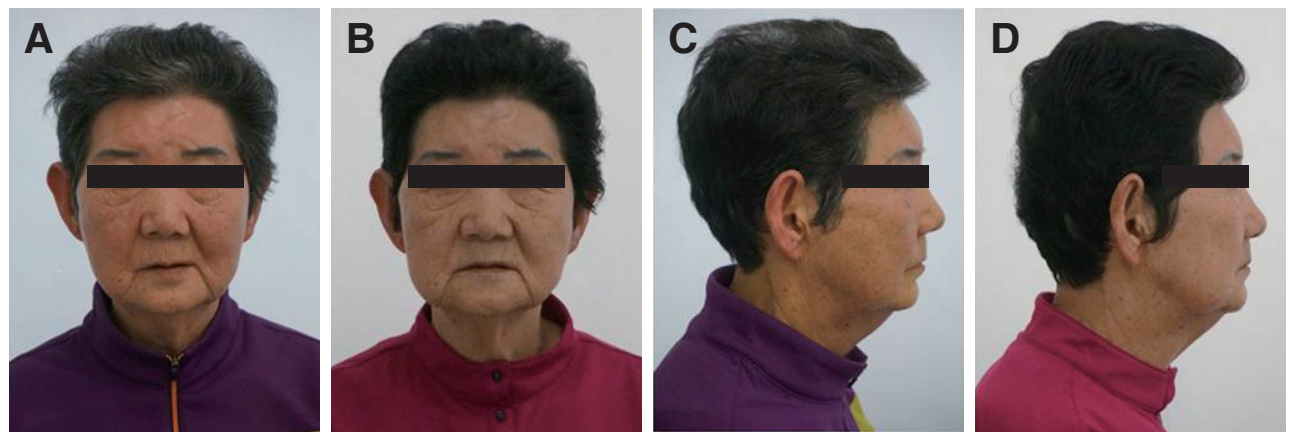

Fig. 10. Patient's profile. (A) Frontal profile of first visit, (B) Frontal profile after definitive denture delivery, (C) Lateral profile of first visit, (D) Lateral profile after definitive denture delivery.

을 통해 기존 의치와 새로 제작한 의치를 인상면 기준으 로 최대 중첩 후 상악 제 1대구치 근심 설측 교두를 기준 으로 cross section하여 단면 분석 시행하였다(Fig. 8). 다 소 우측경사를 보이던 기존 의치에 비해 새로 제작한 의 치에서는 균형 잡힌 교합면을 볼 수 있었고, 볼과 입술 혀 등의 근육 운동을 반영하여 좀 더 개선된 두께와 외형의
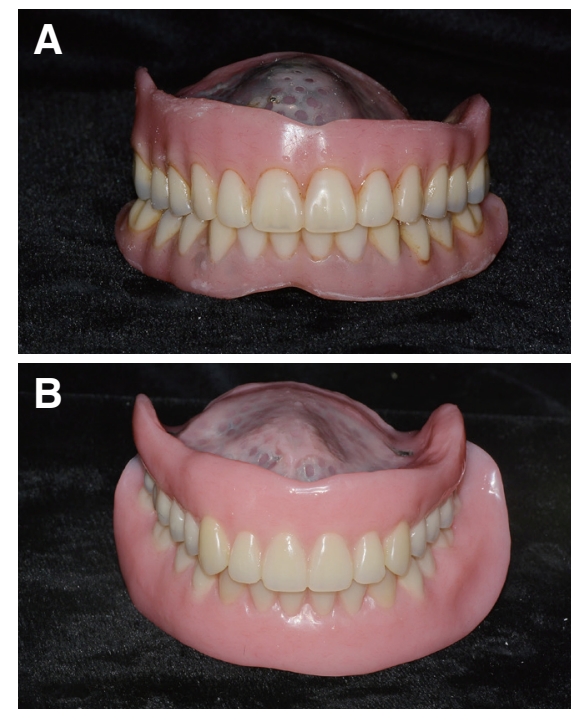

Fig. 9. (A) Pre-existing denture, (B) Definitive denture. 


\section{고찰}

총의치에서 치아배열의 위치와 변연의 형태 및 윤곽 은 다른 어떤 요소보다도 안정성에 큰 영향력을 끼친다. Lammie 등에 의하면 2년 이상 무치악 상태가 지속된 환 자에서는 중립대의 위치는 다소 설측으로 이동되는 경향 이 있다고 언급한 바 있으며, 본 증례에서 중립대를 반영 하여 제작한 새로운 의치의 단면 분석 시에도 새로운 의 치가 기존 의치에 비해 구치부 치아들이 다소 설측으로 배열된 것을 발견할 수 있었다. ${ }^{3}$ 이러한 점들로 미루어 봤 을 때 항상 치조정에 치아가 배열되어야 하는 것은 아니 며 환자 개개인의 근신경계가 이루는 평형상태를 고려한 치아배열이 이루어져야 한다. 그리고 이것이 바로 중립대 를 통한 접근법의 목표이다. 중립대 인상 기법을 통해 중 립대를 고려하여 의치를 제작하게 되면 치아가 정상적인 근육의 기능을 방해하지 않도록 할 수 있으며, 더불어 의 치에 대항하여 가해지는 근육의 힘이 의치의 안정과 유지 에 도움이 될 수 있도록 할 수 있다.

본 증례에서는 심한 치조골 소실을 가진 환자에서 중 립대 접근법을 통한 총의치를 제작함으로써 향상된 유 지와 안정을 얻고자 하였다. 또한 중립대 접근법과 더불 어 대칭적인 근육의 움직임을 좀 더 잘 반영하기 위해서 는 정확한 중심위를 찾아내는 것이 중요할 것으로 여겨 져 고딕아치 묘기법으로 악간관계를 채득하였다. 고딕아 치 묘기법의 경우 왁스 교합제를 이용한 직접적 악간 기 록법보다 중심위를 인지하는 술자의 능력과 기록 매개체 (recording medium)에 의한 영향력을 최소한으로 받기 때문에 정확성이 향상될 수 있다.

그리고 중립대를 기록하기 위한 재료를 선정함에 있어 서는 2 가지의 중요한 고려사항이 요구된다. 우선 재료의 수직적 적층이 수월해야 하며, 근신경계의 형태를 충분하 게 인기해 낼 수 있는 조작 시간이 충분해야 한다. 조직조 정재, 왁스, 산화아연유지놀계 인상재, 실리콘 재료, 아크 릴릭 레진 등을 사용할 수 있으며 각각의 재료의 장,단점 을 파악하여 적합한 재료를 선정하는 것이 중요하다. 모 델링 콤파운드의 경우 다루기가 쉽고 가격이 싸다는 장 점이 있고, 조직조정재의 경우에는 재료를 혼합하여 준 비하기가 쉽고 기능 시 가동조직의 형태를 잘 채득할 수 있을 만큼 충분한 작업시간을 갖는다는 것이 장점이다. 또한 여러겹으로 적층하여 채득이 가능하므로 신경계 손 상이 있는 환자에서 느리거나 혹은 정확하지 않은 반응 이 많은 경우에 적합한 재료로 쓰일 수 있다. 그러나 비용
측면에서 비싸다는 단점이 있다. 아크릴릭 레진은 충분 한 작업시간과 매끈한 표면을 얻을 수 있다는 것이 장점 이지만 모노머의 사용이 문제가 될 수 있다는 단점이 있 다. 본 증례에서는 조작과 비용측면에서 접근성이 좋은 모델링 콤파운드를 이용하여 중립대를 기록하였으며, 이 를 바탕으로 제작한 퍼티 인덱스는 의치 금속상 위에 형 성한 왁스 교합제에 적용되어 중립대 내에 정확하게 치 아가 배열될 수 있도록 가이드 역할을 해준다.

연마면 인상은 인상재의 부피와 작업 시간 동안 가하 는 기능운동에 영향을 크게 받게 되므로 한번에 시행하 기보다는 부분적으로 나누어 채득을 하는 것이 정확성을 높이는데 유리할 수 있다. 기존의치와 중립대를 반영하 여 제작한 의치의 단면을 비교해보면 새로 제작한 의치 에서 좀 더 풍융하고 자세하게 주변 근육의 형태를 반영 하며 균형 잡힌 연마면을 관찰할 수 있었다.

Kokubo 등에 의하면 상, 하악골 절제술이나 신경계 질 환, 파킨슨병 등을 가진 환자에서 임플란트 식립을 진행 하지 못하는 경우에도 향상된 유지력과 안정성을 제공 할 수 있는 방법으로 중립대 개념이 도입될 수 있다고 하 였다. ${ }^{4}$ 그러나 이러한 결과들은 근육의 움직임을 정확하 게 인기 했다는 전제하에 나온 것들이며, 그렇지 못할 경 우에는 최적의 중립대 위치를 찾아내는데 어려움이 있을 수 있기에 구강악안면 부위에 외상이나 질환을 가진 환 자에서도 이 개념을 적절히 적용할 수 있는 방법과 정확 한 기록을 위한 테크닉과 재료 선정에 대한 고려 등은 장 기적으로 좀 더 연구되어야 할 부분으로 보여진다.

\section{결론}

본 증례에서는 심한 치조제 흡수를 동반한 환자에게 중립대 인상 기법을 적용한 총의치를 제작함으로써 향상 된 안정과 유지와 더불어 만족스러운 심미성을 제공하였 다. 중립대 인상 기법은 심한 잔존 치조제의 흡수뿐만 아 니라 통상적인 의치로는 유지와 안정을 얻기 힘든 환자 에서 임플란트 식립이 어려울 경우 좋은 대안이 될 수 있 을 것으로 보여진다.

\section{ORCID}

Yujin Jo https://orcid.org/0000-0002-4096-9137

Chang-woo Ko https://orcid.org/0000-0002-1973-5627

Sang-Won Park https://orcid.org/0000-0002-9376-9104 
Kwi-Dug Yun https://orcid.org/0000-0002-2965-3967

Chan Park https://orcid.org/0000-0001-5729-5127

Hyun-Pil Lim https://orcid.org/0000-0001-5586-1404

\section{References}

1. Beresin VE, Schiesser FJ. The neutral zone in complete dentures. 1976. J Prosthet Dent 2006;95:93100.

2. Beresin VE, Schiesser FJ. The neutral zone in complete and partial dentures. 2nd ed. St. Louis; CV Mosby; 1978.

3. Lammie GA. Aging changes and the complete lower denture. J Prosthet Dent 1956;6:450-64.

4. Kokubo Y, Fukushima S, Sato J, Seto K. Arrangement of artificial teeth in the neutral zone after surgical reconstruction of the mandible: a clinical report. J Prosthet Dent 2002;88:125-7. 


\section{치조제 흡수가 심한 무치악 환자에서 중립대 및 연마면 인상을 통한 총의치 수복 증례}

\section{조유진, 고창우, 박상원, 윤귀덕, 박찬, 임현필*}

전남대학교 치의학전문대학원 보철학교실

심하게 흡수된 치조제에서 안정적으로 유지될 수 있는 의치를 제작하기 위해서는 적절한 교합의 형성뿐만 아니라 주변 근육 조직과의 조화를 고려한 적절한 연마면의 형성에 대한 고려가 필요하다. 중립대 인상 기법을 통해 기능하는 동안 혀, 볼, 입술에 대한 근신경계가 평형을 이루는 잠재적인 영역을 고려하여 인공치아를 배열하고, 연마면 형태가 동적인 근 육의 해부학적 형태를 따르도록 할 수 있으며, 이는 의치의 안정과 유지 및 심미성을 향상시킬 수 있다. 본 증례는 심한 잔존 치조제의 흡수를 보이는 환자에게 중립대 개념을 적용하여 기능과 심미적인 측면에서 임상적으로 만족할 만한 결 과를 얻었기에 이를 보고하고자 한다.

(구강회복응용과학지 2018;34(4):324-30)

주요어: 총의치; 중립대; 연마면 인상 